\title{
Expression of adhesion molecule CD44 on human corneas
}

\author{
Su-Ning Zhu, Bernhard Nölle, Gernot Duncker
}

\begin{abstract}
Aims-This study was undertaken to confirm the distribution and expression of the molecule CD44 on human corneas under normal and pathological conditions.

Methods-Fifty eight corneal buttons from adult patients suffering from various corneal diseases and four normal corneas were included in this study. Frozen sections were stained immunohistochemically with monoclonal antibodies against human CD44 using an APAAP method and observed under a light microscope.

Results-In normal corneas CD44 was predominantly expressed on the membranes of basal epithelial cells and on the keratocytes, as well as on the vascular endothelial cells of the corneal limbi, but was not expressed on corneal endothelial cells. Enhanced expression of CD44 was observed on the epithelium of corneas with inflammation and allograft rejection. In a number of abnormal conditions including allograft rejection, corneal trauma, primary and secondary corneal endothelial decompensation the remaining endothelial cells stained positively for CD44. However, in some corneas of keratitis, keratoconus, and dystrophy the endothelium which appeared relatively integral in morphology and amount remained CD44 negative.

Conclusions-These results suggest that CD44, the hyaluronate receptor, may play an important role in corneal cell-cell and cell-matrix interactions. Its regulation is closely related to corneal inflammatory reactions. The induction of CD44 on corneal endothelium might play a potential role in compensatory processes when corneal endothelial cells are injured.

(Br F Ophthalmol 1997;81:80-84)
\end{abstract}

University Eye Hospital, Kiel, Germany

S-N Zhu

B Nölle

G Duncker

Correspondence to: Professor Dr med G Duncker, Klinik für Ophthalmologie der Christian-Albrechts-Universität zu Kiel, Hegewischstrasse 2, D-24105 Kiel, Germany.

Accepted for publication 16 September 1996
CD44, the hyaluronate receptor, ${ }^{1}$ is a transmembrane glycoprotein which was recognised as a cell adhesion receptor that takes part in cell-cell and cell-matrix interaction such as cell migration, lymphocyte homing and activation, and tumour growth and metastasis. ${ }^{2-4}$ The main haematopoietic form of CD44 has a molecular weight of $85-95 \mathrm{kDa}^{56}$ There are some variant CD44 isoforms (CD44v) induced by alternate splicing of multiple exons into the extracellular domain and by different post-translational modifications in different cell types. ${ }^{3} 7$ CD44 may bind its ligand hyaluronan in response to antigenic stimuli and may participate in the effector stage of immunological responses, ${ }^{8}$ and be capable of binding fibronectin, laminin, and collagen I. ${ }^{69}$

In corneal disorders such as keratitis and corneal allograft rejection some cell adhesion molecules have been shown to be involved in the pathological processes. $^{10-13}$ However, whether CD44 participates in the processes of corneal diseases is less well known. There have been very few studies of CD44 in human corneas and the existing reports on the distribution of CD44 on corneal tissues differ. Alho and Underhill reported that CD44 was absent from human corneal epithelium, ${ }^{14}$ and Foets and colleagues showed that corneal endothelial cells were negative for CD44, but also reported a 'garland-like' positive pattern of expression in corneal endothelial flat mounts of organ cultured corneas. ${ }^{15}$ However, on rabbit corneas Asari et al observed that corneal keratocytes were positive for CD44, in addition to epithelial cells and the apical borders of endothelial cells. ${ }^{16}$ To confirm further the distribution and expression of CD44 on the corneas we performed an immunohistochemical study on human corneas with an APAAP staining technique.

\section{Material and methods}

SPECIMENS

Fifty eight corneal buttons from adult patients suffering from various corneal diseases were collected during penetrating keratoplasty. They were classified into inflammation related or non-inflammation related groups according to the aetiology (Table 1). Four normal corneas from donor eyes (age 56-74, mean 66 years) which did not meet the rigid standards of the Kiel cornea bank were used as controls. One quarter of each of the corneas was snap frozen in Tissue-Tek OCT by immersion in liquid nitrogen. Frozen sections $6 \mu \mathrm{m}$ thick were prepared with a cryostat, air dried overnight at room temperature, then fixed in acetone for 10 minutes and stored at $-20^{\circ} \mathrm{C}$.

IMMUNOHISTOCHEMISTRY

The monoclonal antibodies used for detecting CD44 were F10-44-2 (Biozol, Germany) and J173 (Dianova, Germany). Both of them were diluted 1:50 with phosphate buffered saline containing $1 \%$ bovine serum. The alkaline phosphatase anti-alkaline phosphatase (APAAP) method was used with modifications. ${ }^{17}$ Briefly, the sections were postfixed with chloroform for 10 minutes and then incubated 
Table 1 Clinical data of the patients involved in the study

\begin{tabular}{|c|c|c|c|c|}
\hline Clinical diagnosis & No & $\begin{array}{l}\text { Mean age/range } \\
\text { (years) }\end{array}$ & $\begin{array}{l}\text { Sex } \\
(M / F)\end{array}$ & $\begin{array}{l}\text { Interval (range)* } \\
\text { (months) }\end{array}$ \\
\hline \multicolumn{5}{|l|}{ Inflammation related: } \\
\hline Keratitis & 9 & $67.2 / 58-76$ & $4 / 5$ & $127.4(10-360)$ \\
\hline Graft rejection & 8 & $53.5 / 20-84$ & $3 / 5$ & $46.6(3-204)$ \\
\hline Alkaline burn & 3 & $52.3 / 42-65$ & $3 / 0$ & $146.7(77.5-420)$ \\
\hline Corneal trauma & 2 & $28.5 / 23-36$ & $1 / 1$ & $10.5(0.5-10)$ \\
\hline \multicolumn{5}{|l|}{$\begin{array}{l}\text { Non-inflammation related: } \\
\text { Pseudophakic bullous }\end{array}$} \\
\hline keratopathy & 15 & $68.7 / 30-83$ & $8 / 7$ & $48.5(3-118)$ \\
\hline $\begin{array}{l}\text { Graft endothelial failure } \\
\text { Fuchs' endothelial }\end{array}$ & 2 & $51 / 50-52$ & $2 / 0$ & $40.5(33-48)$ \\
\hline dystrophy & 6 & $71.8 / 65-79$ & $2 / 4$ & $\mathrm{n}$ \\
\hline Keratoconus & 9 & $31.1 / 22-45$ & $6 / 3$ & $13.2(9-18$ years $) \dagger$ \\
\hline Scrofulous scar & 2 & $56 / 37-75$ & $2 / 0$ & $\mathrm{n}$ \\
\hline Lattice dystrophy & 1 & 67 & $\mathrm{~F}$ & $\mathrm{n}$ \\
\hline Meesmann dystrophy & 1 & 64 & $\mathrm{~F}$ & $\mathrm{n}$ \\
\hline
\end{tabular}

*Time periods (months) from the first clinical event (for keratitis, alkaline burn, and corneal trauma) or previous surgery (for graft rejection, graft failure, and pseudophakic bullous keratopathy) to the corneal allografting.

†Time period (years) from the initiation of spectacle wearing to the keratoplasty.

$\mathrm{n}=$ not confirmed

successively with the primary antibody for 30 minutes, a rabbit anti-mouse immunoglobulin (Dako, Germany, diluted 1:50) for 30 minutes, and the APAAP complex (Dako, Germany) for 30 minutes. Finally, the alkaline phosphatase reaction was developed with the substrate naphthol AS-BI phosphate/new fuchsin (Sigma, Germany). The slides were counterstained with haematoxylin and then mounted with glycergel. All incubation steps were performed at room temperature in a humid chamber and followed by thorough washing of the slides with three changes of TRIS buffered saline ( $\mathrm{pH}$ 7.6). Positive controls were obtained using the antibodies on cryosections of human tonsil. Negative controls were prepared with normal mouse serum (Dako, Germany) instead of the primary antibody. The intensity of staining was evaluated qualitatively by two independent observers under a Zeiss light microscope as: - no cells stain; + part of the cells stain; ++ all cells or nearly all cells stain.

\section{Results}

Staining with the two monoclonal antibodies F10-44-2 and J173 showed identical results.

Table 2 Expression of CD44 on human corneal tissue

\begin{tabular}{|c|c|c|c|c|}
\hline Clinical diagnosis & No & Epithelium & Stroma cells & Endothelium \\
\hline Normal & 4 & + & $++^{\mathrm{A}}$ & - \\
\hline \multicolumn{5}{|l|}{ Inflammation related: } \\
\hline Keratitis & 9 & $+^{2}++^{6}(1)$ & $++^{\mathrm{BC}}$ & $--^{7 \mathrm{D}}++^{2}$ \\
\hline Graft rejection & 8 & $++{ }^{7}(1)$ & $t^{2}++^{6 \mathrm{BC}}$ & $+^{5}++^{1}(2)$ \\
\hline Alkaline burn & 3 & ++ & $++^{\mathrm{C}}$ & $++^{1}-^{2 \mathrm{D}}$ \\
\hline Corneal trauma & 2 & ++ & $++^{\mathrm{BC}}$ & ++ \\
\hline \multirow{2}{*}{\multicolumn{5}{|c|}{$\begin{array}{l}\text { Non-inflammation related: } \\
\text { Pseudophakic bullous }\end{array}$}} \\
\hline & & & & \\
\hline keratopathy & 15 & $+{ }^{9}++^{4}(2)$ & $+^{2}++^{13}$ & $+^{3}++^{5}(7)$ \\
\hline Graft endothelial failure & 2 & + & ++ & + \\
\hline $\begin{array}{l}\text { Fuchs' endothelial } \\
\text { dystrophy }\end{array}$ & 6 & + & $+^{1}+t^{5}$ & $t^{2}++^{2}(2)$ \\
\hline Keratoconus & 9 & + & $+^{2}++^{7}$ & $-9 \mathrm{D}$ \\
\hline Scrofulous scarring & 2 & + & $+^{1}++^{1}$ & $-^{\mathrm{D}}$ \\
\hline Lattice dystrophy & 1 & + & ++ & $-{ }^{\mathrm{D}}$ \\
\hline Meesmann dystrophy & 1 & + & ++ & ${ }^{\mathrm{D}}$ \\
\hline
\end{tabular}

Numbers in parentheses indicate the number of cases in which no cell layer existed on the slide. Superscript numbers show the number of patients with positive staining at different levels of staining intensity as indicated.

$\mathrm{A}=\mathrm{CD} 44$ positive vascular endothelium in the corneal limbal stroma.

$\mathrm{B}=\mathrm{CD} 44$ positive neovascular endothelium.

$\mathrm{C}=\mathrm{CD} 44$ positive infiltrate.

$\mathrm{D}=$ endothelial cells relatively normal in morphology and amount.
No cell staining was found on the negative controls. The results are summarised in Table 2 .

EXPRESSION OF CD44 ON CORNEAL EPITHELIUM In normal corneas, CD44 was preferentially expressed on the basal layer of epithelial cells with a integral membrane staining pattern (Fig 1A). The staining of wing cells was related to the corneal location. In general, there were fewer CD44 positive wing cells in central epithelium than in peripheral epithelium. In corneal limbus, almost all epithelial layers stained strongly for CD44 (Fig 1B). A higher intensity of CD44 staining, by which all epithelial layers stained, was observed on the epithelium of all corneas with allograft rejection, corneal trauma, alkaline burn, corneas with keratitis except two cases, and four of 15 with pseudophakic bullous keratopathy. This was especially obvious in regions where graft and receptor corneas adjoin, where Bowman's membrane was destroyed, and where epithelium showed abnormal thickening (Fig 1C and D). There were no evident differences in CD44 expression between control corneas and those with keratoconus, Fuchs' endothelial dystrophy, scrofulous scarring, nine of 15 specimens of pseudophakic bullous keratopathy, except that some pathological cases showed varying extents of granular staining pattern on the epithelial membranes (Fig 1E).

\section{EXPRESSION OF CD44 ON CORNEAL STROMA}

CD44 was constitutively expressed on most keratocytes in normal corneas. Vascular endothelium in corneal limbal stroma expressed CD44. Neovascular endothelium in the stroma of corneas with keratitis, allograft rejection and corneal trauma displayed strong intensity of CD44 staining (Fig 1F). In these conditions, CD44 was expressed intensely on a varying number of infiltrating cells within the stroma. No apparent alterations of CD44 staining on the keratocytes in the diseased corneas were observed.

EXPRESSION OF CD44 ON CORNEAL

ENDOTHELIUM

In normal corneas, the endothelial cells were definitely negative for CD44 (Fig 1G). In diseased corneas CD44 expression on endothelial cells showed a close association with the endothelial alterations in morphology and in amount. Under the light microscope, the endothelial cell layer was apparently attenuated and partially denuded in the cases of allograft rejection, graft endothelial failure, Fuchs' endothelial dystrophy, corneal trauma, pseudophakic bullous keratopathy, and two specimens of keratitis. In these cases CD44 was expressed on the remaining endothelial cells (Fig $1 \mathrm{H}$ and I). No CD44 staining was detected on the corneal endothelial cells of the remaining patients including seven cases of keratitis, two of alkaline burn, nine of keratoconus, two of scrofulous scarring, two of Meesmann and lattice dystrophy, in which the endothelial cells 

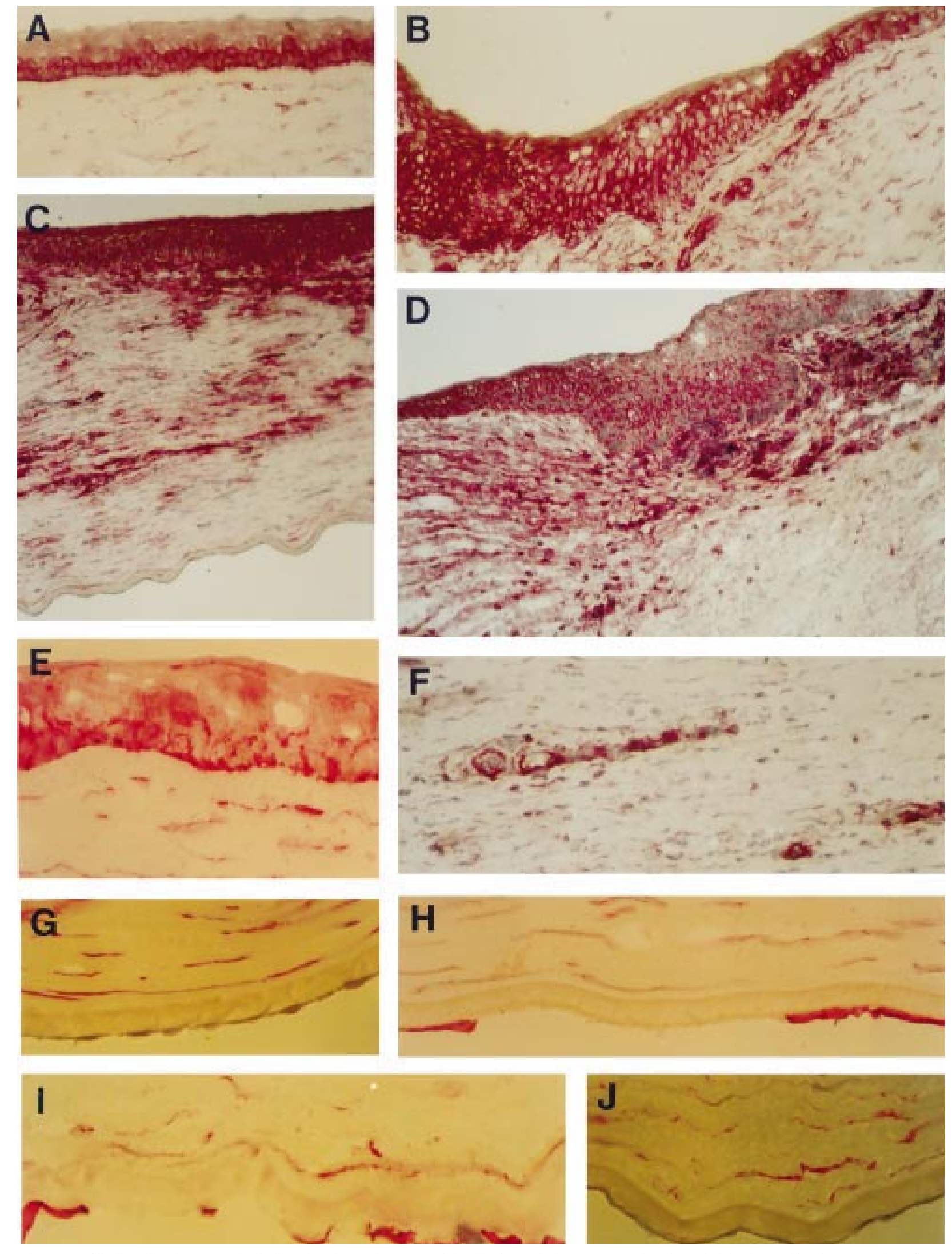

Figure 1 Alkaline phosphatase anti-alkaline phosphatase immunostaining for CD44 in human corneal sections. Original magnification $\times 200$ for $(A)$, (B), (C), (D) and (F); and $\times 400$ for the others. (A) Epithelial cell staining in normal central region; (B) epithelial cell staining in normal limbus; (C) section from a cornea with keratitis showing intense staining in all epithelial layers, but no staining on endothelial cells; (D) section from a cornea with allograft rejection showing the staining of epithelium in the region where graft and receptor corneas adjoin; (E) epithelial cell staining in Fuchs'endothelial dystrophy; $(F)$ CD44 staining on neovascular endothelium and infiltrating cells in cornea with keratitis; $(G)$ normal corneal endothelial cells showing no staining for CD44; (H) section from a cornea with pseudophakic bullous keratopathy showing positive staining on the remaining endothelial cells; (I) section from a cornea with Fuchs'endothelial dystrophy showing the CD44 staining on the remaining endothelial cells; and (f) section from a cornea with keratoconus showing negative staining of endothelial cells for CD44. 
appeared relatively normal in morphology and in amount (Fig 1J and C).

\section{Discussion}

CD44 is an transmembrane adhesion molecule that has a complex structure and function. Its 'standard' form (CD44s), which is a hyaluronan receptor, exists on haematopoietic cells and many other cell types. ${ }^{56}$ In this study, CD44s was detected on the membranes of the corneal epithelial cells. This finding is in keeping with the reports that CD44 exists on epithelial cells of various human tissues including skin, intestine, lung, and kidney. ${ }^{48}$ The different extents of CD44 expression may be a result of a different differentiation pattern related to the epithelial location, and may indicate that CD44 is related not only to the maintenance of normal tissue structure, but also to the proliferative potency of the epithelium, as suggested by some studies. ${ }^{4119}$ Our study showed that normal corneal keratocytes expressed CD44.This is probably also associated with the maintenance of stroma tissue structure. The finding that normal corneal endothelium did not express CD44 is in agreement with the report of Foets and colleagues, ${ }^{15}$ and may suggest a cell type specific expression on corneal tissue. However, whether there is CD44 isotype specific expression on corneal endothelial cells should be confirmed in further studies.

In pathological cases the corneal tissues displayed various expressions of CD44. In keratitis, allograft rejection, corneal trauma, and alkaline burn the expression of CD44 was upregulated on the epithelial layers. This may indicate an association of CD44 with inflammation related conditions, although the significance of the regulation is unclear. The pathological meaning for the alteration of a granular pattern of CD44 staining on epithelial cells by some non-inflammation related specimens needs further study. However, we did not find evidence of upregulation of CD44 on keratocytes in the same cases. This might be explained by: (i) all keratocytes stain already in the normal cornea. Compared with the epithelium, there are no more layers and no other differentiation stadia in the stroma; (ii) a cell type specific regulation; (iii) a disease specific regulation. This is not very likely since CD44 is expressed on most epithelial layers, while the expression of keratocytes stays the same in the same diseased cornea. The expression of CD44 on infiltrating leucocytes and neovascular cells might play different roles during inflammation and graft reaction.

Our most striking finding is that CD44 was produced on corneal endothelial cells. The basis for the CD44 production on the corneal endothelium is unknown. However, our results showed that CD44 production is apparently associated with the integrity of the endothelial layer. It was expressed on the remaining endothelium in Fuchs' endothelial dystrophy, pseudophakic bullous keratopathy, and late stages of corneal allograft rejection, in which the endothelial cells are consistently related to or causative of the pathological process. In the conditions, the endothelial cells (probably no longer normal) have to spread their cell bodies to compensate for the loss of cells and to maintain the endothelial barrier by keeping the Descemet's membrane covered with cells. CD44, however, was not detected on the endothelial cells in the corneas of keratoconus, Meesmann, and lattice dystrophy where it is known that the endothelial cells are not involved in the disease specific pathological processes. It was interesting that the endothelial cells of seven corneas with keratitis remained negative for CD44, although the specimens may represent an end stage of the disease process. This might be explained by the non-involvement of the endothelial layer in these cases, since they appeared still relatively integral. These results suggest an association between CD44 and injury and the consequent compensatory processes of the endothelium. Besides serving as the hyaluronate receptor, CD44 was confirmed to be capable of binding some components of the extracellular matrix, including fibronectin, laminin, and collagen $\mathrm{I},{ }^{69}$ which are important mediators of endothelial functions such as adhesion, spreading, migration, and proliferation. ${ }^{20}$ The induction of CD44 on the remaining endothelial cells might be essential for mediating corneal endothelial cell-cell and cell-Decemet's membrane adherence in cases of endothelial cell damage.

The upregulation of CD44 in inflammatory processes of the skin, rheumatoid arthritis, and sympathetic ophthalmia has been studied previously. ${ }^{21-24}$ The association of CD44 with inflammation was further supported by some in vitro studies in which CD44 was upregulated by some inflammatory cytokines on various cell types such as NK cells, ${ }^{25}$ epidermal Langerhans cells, ${ }^{26}$ endothelial cells, myelomonocytic cell lines, and some epithelial cell lines. ${ }^{47}$ It seems likely that the CD44 regulation is disease and isoform specific, as suggested by Rosenberg and colleagues. ${ }^{28}$ Their cytochemical study on biopsy samples from various types of human colitis showed significantly increased epithelial expression of CD44 isoforms containing the v6 and v3 epitopes. The implication was that varying CD44 isoform expression could potentially help to differentiate ulcerative colitis from Crohn's disease and other forms of colonic inflammation. In addition, a recent study revealed that CD44 expression increased significantly on cytomegalovirus infected human embryonic fibroblasts, but decreased in herpes simplex virus 1 and varicella zoster virus infected human embryonic fibroblasts, ${ }^{29}$ also suggesting a disease specific regulation of CD44.

CD44 has been known to be associated with the activation and migration of lymphocyte to secondary lymphoid tissue via adhesion to high endothelial venules. ${ }^{30-32}$ However, the actual mechanism by which CD44 plays roles in the immune activity related to tissue transplantation remains uncertain. Evidence is accumulating to demonstrate the participation of stimulated cells expressing high levels of CD44 in 
immunological responses in vivo. Mobley and Dailey observed the appearance of a minor Mel-14 negative, high CD44+ population of CD8+ cells in lymph nodes draining an allograft. ${ }^{33}$ Mobley et al found that late after rejection of minor histocompatibility Ag disparate skin grafts, the majority of memory CD8 $\mathrm{T}$ cells express CD $44 .{ }^{34}$ A recent study using sheep renal allografts revealed that alternatively spliced CD44 mRNA appeared as early as day 1 after transplantation and peaked between days 3 to $5 .{ }^{35}$ Similarly, in a rat small bowel graft model significantly increased CD44 expression was detected in the lamina propria on days 5 to 7 , and it was suggested that CD44 expression on enterocytes may provide an early indicator of a developing rejection response. ${ }^{36}$ Recently, some studies noticed a relation between CD44 modulation and cytotoxic activity of NK cells, ${ }^{3738}$ indicating that CD44 may be involved in the effector stage of immune responses.

In this report we have demonstrated the distribution and expression of CD44s on human corneal tissues. The various expressions of CD44 we observed suggests that the hyaluronate receptor might be closely associated with the pathological processes of some corneal diseases, although the most specimens investigated in this study were samples of the end stage of the diseases. Further investigations on the expression and function of various CD44 isoforms on human corneas need to be done. Future studies should also focus on the time course and functional relation with other biological regulating systems.

1 Aruffo A, Stamenkovic L, Melnick M, Underhill, GB, Seed B. CD44 is the principal cell-surface receptor for hyaluronate. Cell 1990;61:1303-13.

2 Günthert U. CD44: a multitude of isoforms with diverse functions. Curr Top Microbiol Immunol 1993;184:47-63.

3 Lesley J, Hyman R, Kincade PW. CD44 and its interaction Lesley J, Hyman R, Kincade PW. CD44 and its interaction
with extracellular matrix. Adv Immunol 1993;54:271-335.

4 Mackay CR, Terpe HJ, Stauder R, Marston WJ, Stark H, Gackay CR, Terpe HJ, Stauder R, Marston WJ, Stark H, Günthert U. Expression and modulation of CD
isoforms in humans. $\mathcal{F}$ Cell Biol 1994;124:71-82.

5 Cam RL, Kraus TA, Pure E. Variations in the cytoskeletal interaction and posttranslational modification of the CD44 homing receptor in macrophages. F Cell Biol 1991;115 1283-92.

6 Jalkanen S, Jalkanen M. Lymphocyte CD44 binds COOHterminal heparin-binding domain of fibronectin. $\mathcal{f}$ Cell Biol 1992;116:817-25.

7 Salmi M, Gron-Virta K, Sointu P, Grenman R, Kalimo H, Jalkanen S. Regulated expression of exon V6 containing isoforms of CD44 in man: downregulation during malignant transformation of tumors of squamocellular origin. $f$ Cell Biol 1993;122:431-2.

8 Rodrigues M, Nussenzweig RS, Romero P, Zavala F. The in vivo cytotoxic activity of $C D 8+T$ cell clones correlates with their levels of expression of adhesion molecules. $\mathcal{F}$ Exp with their levels of express

9 Carter WG, Wayner EA. Characterization of the class III collagen receptor, a phosphorylated, transmembrane glycocollagen receptor, a phosphorylated, transmembrane glycoprotein expressed in

10 Elner VM, Dutt S, Pavilack MA, Sugar A, Foster CS, Elner SG. Intercellular adhesion molecule-1 (ICAM-1) and HLA-DR antigens in herpes keratitis. Ophthalmology 1992 99:1400-7.

11 Philipp W. Leukocyte adhesion molecules in rejected corneal allografts. Graefes Arch Clin Exp Ophthalmo 1994;232:87-95.

12 Goldberg MF, Ferguson TA, Pepose JS. Detection of cellular adhesion molecules in inflamed human corneas. Ophthalmology 1994;101:161-8.

13 Vorkauf W, Vorkauf M, Nölle B, Duncker G. Adhesion molecules in normal and pathological corneas-an immuno- histochemical study using monoclonal antibodies. Graefes Arch Clin Exp Ophthalmol 1995;233:209-19.

14 Alho AM, Underhill CB. The hyaluronate receptor is preferentially expressed on proliferating epithelial cells. $\mathcal{F}$ Cell Biol 1989;108:1557-65.

15 Foets BJ, van den Oord JJ, Volpes R, Missotten L. In situ immunohistochemical analysis of cell adhesion molecules on human corneal endothelial cells. Br F Ophthalmol 1992; 76:205-9.

16 Asari A, Miyauchi S, Takahashi T, Kohno K, Uchiyama Y. Localization of hyaluronic acid, chondrotin sulfate, and CD44 in rabbit cornea. Arch Histol Cytol 1992;55:503-11.

17 Cordell JL, Falini B, Erber WN, Ghosh AK, Abdulaziz Z, MacDonald S, et al. Immuno-enzymatic labeling of monoclonal antibodies using immune complexes of alkaline (APAAP complexes). f Histochem Cytochem 1984;32:21929.

18 Fox SB, Fawcett J, Jackson DG, Collins I, Gatter KC, Harris AL, et al. Normal human tissues, in addition to some umor, express multiple different CD44 isoforms. Cancer Res 1994;54:4539-46.

19 Abbasi AM, Chester KA, Talbot IC, Macpherson AS, Boxer $\mathrm{G}$, Forbes A, et al. CD44 is associated with proliferation in normal and neoplastic human colorectal epithelial cells. Eur 7 Cancer 1993;29A: 1995-2002.

20 Underwood PA, Bennett FA. The effect of extracellular matrix molecules on the in vitro behavior of bovine endothelial cells. Exp Cell Res 1993;205:311-9.

21 Penneys NS. CD44 expression in normal and inflamed skin. f Cutan Pathol 1993;20:250-3.

22 Haynes BF, Hale LP, Patton KL, Martin MF, McCallum RM. Measurement of an adhesion molecule as an indicator of inflammatory disease activity. Up-regulation of the receptor for hyaluronate (CD44) in rheumatoid arthritis. Arthritis Rheum 1991;34:1434-43.

23 Johnson BA, Haines GK, Harlow LK, Koch AE. Adhesion molecule expression in human synovial tissue. Arthritis Rheum 1993;36:137-46.

24 Kuppner MC, Liversidge J, McKillop-Smith S, Lumsden L, Forrester JV. Adhesion molecule expression in acute and fibrotic sympathetic ophthalmia. Curr Eye Res 1993;12: 923-34.

25 Maenpaa A, Jaaskelainen J, Carpen O, Patarroyo M, Timonen $T$. Expression of integrins and other adhesion molecules on NK cells: impact of IL-2 on short- and longterm cultures. Int $\mathcal{f}$ Cancer 1993;53:850-5.

26 Osada A, Nakashima H, Furue M, Tamaki K. Up-regulation of CD44 expression by tumor necrosis factor-alpha is neutralized by interleukin-10 in Langerhans cells. F Invest Dermatol 1995;105:124-7.

27 Mackay F, Loetscher H, Stueber D, Gehr G, Lesslauer W. Tumor necrosis factor $\alpha(\mathrm{TNF}-\alpha)$-induced cell adhesion to human endothelial cells is under dominant control of one TNF receptor type, TNF-R55. F Exp Med 1993;177:127786

28 Rosenberg WM, Prince C, Kaklamanis L, Fox SB, Jackson DG, Simmons DL, et al. Increased expression of CD44V6 and CD44V3 in ulcerative colitis but not colonic Crohn's disease. Lancet 1995;345:1205-9.

29 Ito $M$, Watanabe $M$, Ihara $T$, Kamiya $H$, Sakurai $M$. Increased expression of adhesion molecules (CD54, CD29 and CD44) on fibroblasts infected with cytomegalovirus. Microbiol Immunol 1995;39:129-33.

30 Willerford DM, Hoffman PA, Gallatin WM. Expression of lymphocyte adhesion receptors for high endothelium in primates. Anatomic partitioning and linkage to action. $\mathfrak{f}$ primates. Anatomic partitionin

31 Koopman G, Heider KH, Horst E, Adolf GR, van den Berg F, Ponta H, et al. Activated human lymphocytes and aggressive non-Hodgkin's lymphomas express a homoogue of the rat metastasis-associated variant of CD44. 7 Exp Med 1993;177:897-904

32 Woodruff JJ, Clark LM, Chin YH. Specific cell-adhesion mechanisms determining migration pathways of recirculating lymphocytes. Annu Rev Immunol 1987;5:201-22.

33 Mobley JL, Dailey MO. Regulation of adhesion molecule expression by CD $8 \mathrm{~T}$ cells in vivo. I . Differential regulation of gp90MEL-14 (LECAM-1), Pgp-1, LFA-1, and VLA-4 alpha during the differentiation of cytotoxic $T$ lymphocytes induced by allografts. F Immunol 1992;148:2348-56.

34 Mobley JL, Rigby SM, Dailey MO. Regulation of adhesion molecule expression by CD8 $\mathrm{T}$ cells in vivo. II. Expression
of L-selectin (CD62L) by memory cytolytic $\mathrm{T}$ cells of L-selectin (CD62L) by memory cytolytic $\mathrm{T}$ cells 1994;153:5443-52.

35 Krishnan R, Kireta S, Carter JK, GroobY WL, Rao MM, Russ GR. Expression of alternatively spliced CD 44 mRNA in sheep renal allografts. Transplant Proc 1995;27:2170-71.

36 Uff CR, Reid SD, Wood RF, Pockley AG. CD44 expression on enterocytes: an indicator of rejection following rat small bowel transplantation. Transplant Proc 1994;26:1553.

37 Galandrini R, de Maria R, Piccoli M, Frati L, Santoni A.CD44 triggering enhances human NK cell cytotoxic functions. F Immunol 1994;153:4399-407.

38 Sconocchia G, Titus JA, Segal DM. CD44 is a cytotoxic triggering molecule in human peripheral blood NK cells. $\mathcal{F}$ Immunol 1994;153:5473-81. 